\title{
Facilitating mCommerce Growth in Nigeria through mMoney Usage: A Preliminary Analysis
}

\author{
Christian Nedu Osakwe \\ Tomas Bata University, \\ Zlin, Czech Republic
}

\author{
Titus Chukwuemezie Okeke \\ Nnamdi Azikiwe University, \\ Awka, Nigeria
}

tc.okeke@gmail.com

\begin{abstract}
A general belief is that Mobile Money (mMoney) has the catalytic effect of spurring mCommerce growth and driving financial inclusion in developing nations like Nigeria. In Nigeria, mMoney service is certainly a new financial service innovation in the country, and as a result critical issues surrounding its early critical mass adoption, including its perceived usefulness, remain largely opaque. In this paper, our aim was to explore factors influencing perceived usefulness of mMoney by using the extended technology acceptance model (TAM) as the theoretical underpinning of our work. This work is based on a usable sample of 127 respondents from two major cities in Nigeria. Overall, the study's results indicate that perceived regulator assurance, service affordability, convenience, proximity to the nearest bank branch, and worry over ease of use are significant predictors of mMoney perceived usefulness. The work helps shed new insights about the significant factors that are closely related to the consumer's perception of the relevance of mMoney services (to his/her financial needs). In sum, the study is an initial step to addressing the issue of perceived usefulness of mMoney service, including its pivotal importance to laying a solid foundation for mCommerce growth in Nigeria and similar sub-Saharan African (SSA) countries.
\end{abstract}

Keywords: BoP, consumer behaviour, financial inclusion, mMoney, mCommerce, Nigeria, SSA.

\section{Introduction}

The advent of the mobile phone, as well as the Internet, has continuously brought with it so many innovations. One of such has been the emergence of mobile commerce (mCommerce), which to a very large extent makes payment for goods and services not only quite convenient but also flexible for today's increasingly digitally savvy consumer (Bang, Han, Animesh, \& Hwang, 2013; Boadi, Boateng, Hinson, \& Opoku, 2007; Cao, Lu, Gupta, \& Yang, 2015). Globally, millions of

Material published as part of this publication, either on-line or in print, is copyrighted by the Informing Science Institute. Permission to make digital or paper copy of part or all of these works for personal or classroom use is granted without fee provided that the copies are not made or distributed for profit or commercial advantage AND that copies 1) bear this notice in full and 2) give the full citation on the first page. It is permissible to abstract these works so long as credit is given. To copy in all other cases or to republish or to post on a server or to redistribute to lists requires specific permission and payment of a fee. Contact Publisher@InformingScience.org to request redistribution permission.

\section{businesses are now conducted 'on the} go' with the aid of the mobile phone. Worldwide, the value of mCommerce transactions is expected to rise from $18 \mathrm{~B}$ USD in 2012 to 117B USD in 2017. Equally, the volume of transaction is expected to rise from $1 \%$ in 2012 to $3 \%$ in 2017 (WorldPay, as cited in VantageB2B, 2014). The same study by WorldPay indicates that $66 \%$ of electronic transactions (eTransactions) in 
Africa/Middle East were made using non-card methods, the estimated electronic commerce (eCommerce) turnover in Nigeria in 2012 was put at 0.9B USD, and mobile payments accounted for $19.6 \%$ of the eCommerce mix by payment type. It is interesting to know that developing countries, including sub-Saharan African (SSA) nations, are equally taking advantages of the affordances of the mobile phone (Aker \& Mbiti, 2010; Boateng, Hinson, Galadima, \& Olumide, 2014). Unarguably, SSA countries have within the last decade witnessed a tremendous traction in the usage of mobile phones (cf. Nabareseh, Osakwe, Klimek, \& Chovancova, 2014; Osakwe, 2013). What was hitherto seen as the exclusive preserve of the few rich people in SSA countries has now become a mass-commodified product (Osakwe, 2013). Needless to say, the pervasiveness of the mobile phone has provided new business opportunities in both the developed and developing nations. The major point to stress is that in the case of several developing economies, the rise of the mobile phone has indeed provided a viable pipeline, which seamlessly connects the formal sector to the informal sector of these nations (for instance, see Aker \& Mbiti, 2010; Boateng, 2011; Boateng et al., 2014).

Meanwhile current developments within the digital commerce (e.g., mCommerce) landscape in SSA countries including Nigeria are anything but robust at this stage (Ayo, Ekong, Fatudimu, \& Adebiyi, 2007; Boateng et al., 2014). This might be partly attributable to a dearth of robust electronic financial transactions' systems. Arguably, the advent of mMoney in the SSA region offers the possibilities of facilitating mCommerce growth potentials in the region. mMoney is simply a form of mobile-enabled localized banking cum payment system that relies heavily on the availability of agents' network (cash-in-cash-out centres) (Chauhan, 2015; Cobert, Helms, \& Parker, 2012; Osakwe, 2013). In other words, mMoney could be seen as a form of electronic money that is readily available on a mobile device and that can be easily converted into cash equivalent and/or transmitted electronically to a third party. It is pertinent to point out that mobile banking (mBanking) differs from mMoney in the sense that the former is strictly an add-on service to existing conventional banks' customers while the latter can be seen as an alternative banking channel to serve the hitherto unbanked and underbanked segments that are predominantly part of the Bottom of the Pyramid (BoP) market in most developing economies (also, see Chauhan, 2015; Osakwe, 2013). Within the SSA region, $76 \%$ of its adult population do not have formal bank accounts with only $15 \%$ and $3 \%$ of the adult population having a debit card and credit card respectively (Demirguc-Kunt \& Klapper, 2012).

In a 2012 survey by Enhancing Financial Innovation \& Access (EFInA), 40\% of adult Nigerians were reported to have zero access to formal and informal financial services-delivery channels. Similarly, a report by the Consultative Group to Assist the Poorest (CGAP) (as cited in Mendelson, 2012) showed that out of the 2.55 billion adults worldwide without access to a formal bank account, about $93.3 \%$ of the adult population without formal financial access were from the developing world. Rather surprisingly, out of the 2.55 billion unbanked adults, 1.7 billion adults were reported to have mobile phones (Castri, 2013). Interestingly also, a recent mobile money insight report by the Mobile Ecosystem Forum (MEF) (2014) covering 13 countries says that mMoney users have a higher propensity to make purchases via their mobile devices than the typical mobile user. The report brings to the fore the synergy between mMoney dynamics and mCommerce growth potentials in developing countries, and most notably SSA.

Undoubtedly, Nigeria with a population of nearly 170 million people has a huge potential of becoming one of the leading global players within the mobile ecosystem owing to tremendous growth in teledensity within the last twelve years. Teledensity is often defined to be the number of telephone lines including mobile and fixed wired/wireless lines per 100 inhabitants in a given geographical area (cf. Garcia-Murillo, 2003; ITU, 1998; Mbarika, Okoli, Byrd, \& Datta, 2005). From a mere teledensity of $0.73 \%$ in 2001, the teledensity as of December, 2015 stood at $107.87 \%$ (Nigerian Communication Commission [NCC], 2016). Unfortunately, the country's 
growing teledensity is yet to significantly translate to building the critical mass needed for the effective uptake of mMoney among its targeted users (see Phillips Consulting, 2013; Osakwe, 2013).

More recently, the Central Bank of Nigeria $(\mathrm{CBN})$ introduced a new policy, the cashless policy, the aims of which are to reduce the amount of cash in circulation and to enhance financial inclusion of the unbanked and under banked (CBN, 2012). According to numerous reports (e.g., see CBN, 2013; Egbuta, 2013; Phillips Consulting, 2013; RTC Advisory Services Ltd., 2013), mMoney is one of the tools that has been marked for the effective implementation of the cashless policy; hence mMoney is critical for the success of the policy. However, recent country-wide surveys and practitioners' reports show that the adoption rate of mMoney is still a far cry from mobile phone explosion in the country (cf. NOIPolls, 2013; Phillips Consulting, 2013).

Scaling up mMoney adoption in Nigeria demands an understanding of customer value propositions of the service. Accordingly, our study is aimed at understanding the important factors that underlie perceived usefulness of mMoney in the country. In sum, the critical research question that prompted this study is: What factors significantly influence the positive perception of mMoney perceived usefulness amongst prospective consumers in the Nigerian nation? Doubtless researchers and theorists have employed several theories in the process of ascertaining consumer adoption of an innovation. Popular theories in the field include the technology acceptance model (TAM), theory of reasoned action (TRA), innovation diffusion model, and extended TAM. This paper is based on extended TAM that allows for incorporation of environmental variables. More specifically, in this preliminary study, it is our intention to explore the effect of convenience, perceived risk, perceived trust, concern for ease of use, perceived cost effectiveness (i.e., affordability), perceived structural assurance, branch bank distance, and phone network failure on the perceived usefulness of mMoney in Nigeria. In doing so, the paper provides meaningful insights about the significant factors that might be associated with the average Nigerian consumer's perception of the relevance of mMoney services (to his/her financial needs). Additionally, our work complements a recent work (Osakwe, 2013) which was largely qualitative in nature. The paper is further arranged as follows: section two provides some stylized facts of mMoney development in Nigeria including the study's theoretical background. The materials and methods are highlighted in the third section while the important findings of the study and discussion are presented in the fourth section. The fifth section provides summary and conclusion, while the last section points out the limitations of the study together with the direction for future work(s).

\section{Literature Review}

\section{Facts on mMoney Development}

Going by recent statistics of GSMA (2013a), SSA is the fastest growing mobile market region across the globe. As of mid-June 2013, SSA countries had 253 million unique mobile phone subscribers as well as 502 million active mobile phone subscriptions. The mobile ecosystem was equally seen to contribute significantly to SSA regional GDP by $6.3 \%$ in 2012 (60B USD) with a further forecast of $7.1 \%, 7.7 \%$ and 8.2\% of GDP contribution by 2014 (74B USD), 2017 (95B USD), and 2020 (119B USD) respectively. Given that banking penetration in SSA countries, and in particular, Nigeria, is very low (see EFInA., 2012; Olayinka, 2016), mMoney through the use of mobile phone offers the possibilities of offering secure, convenient, and affordable financial services to the BoP segment.

Driving financial inclusion in Nigeria and other SSA countries is a sine qua non for integrating the informal sector to the formal sector. This would inevitably spur not only mCommerce growth, but also the retail market in local economies as a whole. mMoney remains one of the viable chan- 
nels for achieving this lofty goal given the ubiquity of the mobile phone. SSA countries, most notably Kenya, have been the pacesetter in this innovative handy 'always-on' banking service. As of December, 2013, the SSA regions accounted for $51.7 \%$ of the live deployments of mMoney services within the globe (GSMA, 2013b). The same findings by GSMA showed that in June, 2013, they were about 98 million registered mMoney users in SSA, and this figure significantly dwarfs the total number of Facebook users within the region by almost twice.

The successful launch of the iconic mMoney brand, M-PESA (a Safaricom mMoney service), in 2007 has proved to be a success story in Kenya given the mass adoption of the service by both the $\mathrm{BoP}$ and middle of the Pyramid (MoP) segments of the Kenyan market. Figures indicate that out of the 17 million M-PESA users in Kenya, they are about 11.6 million monthly active M-PESA consumers. The M-PESA agent network is currently put at 78,856 mobile agents with monthly growth rates of $16 \%, 88 \%$, and $90 \%$ payment transactions ranging from person-to-person $(\mathrm{P} 2 \mathrm{P})$, person-to-business (P2B), and business-to-person (B2P) transactions respectively (Camner, 2013). It is claimed that M-PESA processes more domestic mobile financial transactions daily than what Western Union does globally (Mas \& Radcliffe, 2011). M-PESA success story in Kenya has facilitated the replication of similar business models in SSA countries and other developing economies in Asia and Latin America. No wonder the East African bloc remains the global leader in terms of both volume and value of mMoney transactions within the global mMoney ecosystem (see Mas \& Radcliffe, 2011; Osakwe, 2013).

Unarguably, the advent of Global System for Mobile Communications (GSM) in August, 2001 sparked a digital revolution in Nigeria and has further set the tone for integrating the nation's nascent digital ecosystem into the global digital landscape. As of 2012, mobile phone household penetration rate was put at $139 \%$, while fixed phone line household penetration rate was put at $1.2 \%$ (GSMA, 2013b). This is a pointer to the fact that mobile phone has been a disruptive innovation in Nigeria. The transition to mobile phone usage within the last one decade has witnessed a tremendous upswing owing to need for both social and business connectivity. It is also on record that a majority of Nigerians can access the Internet only using their mobile phones due largely in part to the high price of laptops and personal computers (PCs). In a recent general household panel survey tagged "Wave 2 2012/2013" conducted by the Nigerian National Bureau of Statistics (NBS) in collaboration with the World Bank Living Standards Measurement Study Group, 14.4 $\%$ of households in urban Nigeria indicated to have access to PCs while a mere $4.3 \%$ in rural areas have access to PCs. Households access to PC in Nigeria is estimated at $8.1 \%$ (see Table 1). The same survey report by NBS (2014) indicates that in wave 1 of the household survey, about $47.1 \%$ of rural households reported expenditure on recharge cards (airtime) while $62.3 \%$ of rural households in Wave 2 of the survey reported that they made purchases of airtime. As expected, about $86.5 \%$ of urban households reported making airtime purchases while the total number of households in Nigeria who reported airtime expenditure constituted $72.3 \%$ in Wave 2 of the household survey.

Table 1. Nigerian Households ICT Access

\begin{tabular}{llllllllll}
\hline ICT & $\begin{array}{l}\text { North } \\
\text { Central }\end{array}$ & $\begin{array}{l}\text { North } \\
\text { East }\end{array}$ & $\begin{array}{l}\text { North } \\
\text { West }\end{array}$ & $\begin{array}{l}\text { South } \\
\text { East }\end{array}$ & $\begin{array}{l}\text { South } \\
\text { South }\end{array}$ & $\begin{array}{l}\text { South } \\
\text { West }\end{array}$ & $\begin{array}{l}\text { Urban } \\
\text { Nigeria }\end{array}$ & Rural & Nigeria \\
& Nigeria \\
\hline Television & 59.9 & 33.9 & 28.0 & 74.2 & 88.7 & 83.1 & 88.1 & 44.0 & 60.9 \\
Radio & 86.7 & 84.5 & 85.8 & 90.3 & 90.1 & 95.5 & 92.2 & 87.3 & 89.1 \\
PC & 7.5 & 5.7 & 2.9 & 9.9 & 12.8 & 10.9 & 14.4 & 4.3 & 8.1 \\
Mobile & 85.9 & 74.4 & 69.1 & 91.6 & 88.7 & 91.5 & 91.5 & 77.7 & 83.0 \\
$\begin{array}{l}\text { Phone } \\
\text { Internet }\end{array}$ & 7.0 & 3.7 & 2.8 & 8.8 & 11.2 & 10.9 & 14.5 & 3.0 & 7.4 \\
\hline \multicolumn{7}{c}{ Adapted from NBS (2014) }
\end{tabular}


From Table 1, it is evident that the use of mobile phones in Nigeria can possibly act as the synergy between financial inclusion for the BoP segment and mCommerce growth in Nigeria. For the purpose of this work, the author's description of the BoP segment within the context of this study entails Nigerians who live on a subsistence income level of $\$ 1$ to $\$ 3$ a day. Prior to the successful launch of mMoney deployments in Nigeria in August, 2011, most of the deposit money banks (DMBs) were already offering mBanking solutions to their existing clientele as a form of valueadded service. Therefore, the service was only within the reach of the supposedly 28.6 million banked Nigerian adults (EFInA, 2012). The Nigerian apex bank had earlier in June, 2009 developed a mobile payment regulatory framework. Three business models - bank-focused model, bank-led model, and non-bank-led (agnostic model) - were succinctly spelt out within the framework (CBN, 2009). Based on the existing framework, telecoms operators (Telcos) were excluded from the mainstream mMoney service provision. The CBN did adduce the reasons for the exclusion of Telcos, one of the main reasons being that since Telcos are not within the jurisdiction of the financial regulatory body, it would be difficult for the apex bank to monitor Telcos activities. Nonetheless, the CBN sees Telcos as partners in progress since Telcos provide the critical network infrastructure that can drive not only mobile financial transactions but also financial inclusion for the BoP as well as mCommerce in the country. According to the GSMA Mobile Money Tracker (2014), as of March 2014, the total number of mMoney operators (MMOs) in Nigeria stood at nineteen (19).

Arguably, only about one-third of the existing MMOs appear to be gaining traction in the hitherto underbanked and unbanked segments of the Nigerian populace. Aside the bank-led MMOs, it appears that Paga, PocketMoni, and Teasy are the leading brands in the non-bank led model. For instance, in November, 2013, Paga was the first MMO in Nigeria to achieve the one million users' milestone. It boasts of over 3,500 agent networks in 25 of the 36 states in Nigeria with a 33\% active subscriber rate. As of March, 2014 the number of Paga users had risen to about 1.3 million (Paga, 2014). Similarly, the estimated mMoney subscribers in Nigeria currently stands at 9,989,297 while the estimated figure for total number of mobile agents grew from 4,031 in November, 2011 to 67,494 within the third quarter of 2013 (CBN, 2013; Hallmark Newspaper, 2013). From the official figures given by CBN (2016), the volume of mMoney transactions as of February, 2016 stood at 4,522,569 million transactions and it comprises cash-in, cash-out, bill payments, funds transfer, airtime purchase and merchant payment.

Even though official figures emanating from the regulatory body, $\mathrm{CBN}$, appear to show tremendous growth in mMoney mileage in terms of volume and values of transactions processed, the same cannot be truly said of the average Nigerian consumer's attitudinal disposition towards mMoney usage. Two recent surveys (NOIPolls, 2013; Phillips Consulting, 2013) seem to indicate that mMoney is predominantly used by the existing conventional banked customers as a means of airtime purchase and bill payment. Thus, it appears that mMoney is yet to gain traction among its intending users (the hitherto unbanked and underbanked BoP segment). This is not so surprising given the peculiarities of the Nigerian business landscape.

One would argue that scaling up mMoney usage amongst the BoP segment requires a top-down approach (for a start) rather than a bottom-up approach. One of the reasons being that once existing banked customers are able to not only demonstrate explicit confidence in the mMoney system, but also see the value proposition of mMoney service, it would inevitably lead to a greater appreciation of the service and its adoption too. This is more so as the majority of the banked populace in Nigeria live in urban areas and supposedly remit money to their loved ones in rural areas using informal channels like commercial bus drivers and friends or family members (see EFInA, 2012). This also makes the top-down approach much more realistic in this case. In a nationwide poll conducted by NOIPolls, a total of 1,004 respondents participated in the survey. From the simple random sample survey, $51 \%$ of the respondents revealed that they were unaware 
of mMoney services. Further findings from the survey showed that only $13 \%$ of those who were aware of mMoney had adopted the service. In another survey conducted by Phillips Consulting, which was released in September, 2013, 63\% of the 1,987 respondents were aware of mMoney while only about $29 \%$ of the respondents are registered with an MMO. More so, $31 \%$ of the respondents who are registered with MMOs are completely inactive users. For the non-registered users, $29 \%$ cited lack of information on mMoney services as the primary reason for the nonadoption of the service while $27 \%$ are worried about the safety and privacy issues of customers' account information, $23 \%$ expressed concern over the reliability of effective transaction processing while a further $17 \%$ cited lack of perceived need for mMoney. It is equally pertinent to point out that the mMoney report by Phillips Consulting showed that the percentage of registered mMoney subscribers rose from a mere 6\% in 2011 to $40 \%$ as of August, 2013.

\section{Theoretical Background}

In understanding customers' acceptance of innovations, prior works have adapted the TAM model (Davis, 1989) which is strongly connected to the earlier theory of reasoned action (TRA). Briefly, TRA theorizes about the linkages between beliefs, attitudes, and intentional behaviour (Fishbein \& Ajzen, 1975). The TRA beliefs were replaced in the TAM by perceived usefulness (PU) and perceived ease of use (PEOU). In short, according to Davis (1989), the user's attitude towards acceptance of a new system is important for the successful adoption of any information system. To be clear, the quality and effectiveness of a system can only be validated with its level of users' acceptance. It is no wonder that TAM, including its extended version, has been extensively used by scholars in understanding the success factors behind the adoption of mobile financial services (MFS) such as mMoney (cf. Chauhan, 2015; Dass \& Pal, 2011; Tobbin, 2010). In a similar fashion, Morgan and Ravindran (2014) in their work adopted a revised TAM, which the authors referred to as "A Reduced Form Technology Consumer Product Adoption Model" (p. 6) to study important factors impacting the interaction(s) between home Internet and mobile device use in the US context. The model incorporates perceived affordability, perceived risk, and user demographics among others to evaluate US consumers' use of home Internet as well as mobile devices (see Morgan \& Ravindran, 2014). Also, from the perspective of the Kenyan consumers, Lule, Omwansa, and Waema (2012) applied the extended TAM model by adding three variables - transaction cost, perceived norm, and perceived self-efficacy - to study mBanking adoption in Kenya.

Accordingly, this study is based on the extended model, and as earlier hinted, the major variables of interest under study here include the dependent variable (perceived usefulness (PU)) and the following independent variables: concern for ease of use (CfEoU), perceived risk (PR), perceived trust (PT), perceived cost effectiveness (PCE), convenience (CVC), perceived regulator assurance (PRA), phone network failure (PNF), and bank branch distance (BBD).

Perceived Usefulness (PU): Perceived usefulness relates to whether a customer sees a particular system as relevant to the performance of his day to day activities. It is seen as the most prominent belief in TAM and explains that a user's perception about latent benefits of using a technologybased product elicits positive feelings towards it (Davis, 1989; Davis, Bagozzi, \& Warshaw, 1989). Some of the latent benefits for a user (as reported in the literature) are the reduction of time and effort to complete a task, better control during interaction with the system, and greater expediency (see Davis et al., 1989). Equally, empirical evidence shows that PU is a strong predictor of consumer adoption of an innovation like mMoney (cf. Adesina \& Ayo, 2010; Dass \& Pal, 2011; Tobbin, 2010).

Concern for Ease of Use (CfEoU): This refers to the extent to which a customer believes that an innovation is easy to use and that it requires little or no effort to use (Davis, 1989). Concern for ease of use, $\mathrm{CfEoU}$, is obviously one of the dominant constructs in the original TAM model that 
was proposed by Davis (1989). An individual would opt for a product from a range of available options if it requires little or no effort to use (Davis, 1989). Over the years, several studies have clearly demonstrated about the predictive ability of CfEoU on the perceived usefulness of an innovative service as well as its actual adoption rate (for example, see Adesina \& Ayo, 2010; Dass $\&$ Pal, 2011; Tobbin, 2010). Also in the realm of mobile technology use, a number of studies point out the importance of the construct of ease of use in the adoption story of mobile enabled services (e.g., Adesina \& Ayo, 2010; Rusu \& Shen, 2012). What is clear is that past findings substantially agree that $\mathrm{CfEoU}$ plays an important part in in the adoption equation of technologybased services like mMoney. Taken together, it is expected that $\mathrm{CfEoU}$ will play a crucial role in the Nigerian consumers' strong perception about the perceived usefulness of mMoney.

Perceived Risk (PR): In general, the literature on consumer behaviour agrees that risk plays an important part in the decision making process of the consumer. It is evidenced in the broader literature that consumers tend to perceive greater risks when buying services compared to the purchase of tangibles (for instance, see early research by Laroche, McDougall, Bergeron, \& Yang, 2004; Mitchell \& Greatorex, 1993; Mitra, Reiss, \& Capella, 1999; Zeithaml, 1981). According to Zeithaml (1981), this may be due to the non-standardized format of services and not forgetting also that services purchased may not confer any form of warranty or guarantee to the customer. Besides, the technicality alongside the specialty form of some services even makes it quite cumbersome for a typical end-user to 'truly' evaluate his/her satisfaction of the service even after its immediate consumption (Zeithaml, 1981). Simply put and in line with this study, perceived risk is the uncertainty about the outcome of the use of an innovation such as mMoney. Briefly, Riquelme and Rios (2010) assert that risk factor is a vital element in investigating technology adoption; while Morgan and Ravindran (2014) argue that consumers seem more concerned with risk when using mobile devices. In Nigeria, mobile phone theft and reuse issue is a major problem (see Boateng et al., 2014; Ebiye, 2015; Michael, Chinwokwu, \& Arop, 2014). This implies that the greater the potential for loss or theft (of the mobile phone) the greater will be the escalation of perceptions about the security risk of mMoney. Subsequently, this erodes users' confidence in the use of phone-enabled means of financial transactions such as mMoney within the country. A recent study has also found that user's perception of risk is a crucial determinant of innovative technology acceptance in SSA economies like Nigeria (Okeke, 2013). Taken together, it is expected that PR will play an important role in the Nigerian consumers' perception about the perceived usefulness of mMoney.

Perceived Trust (PT): Trust is a critical factor in the success of the adoption of mobile platforms (Masinge, 2010). According to Kim, Chung, and Lee (2011), trust is a psychological expectation that the trusted party will not behave opportunistically. It is defined as the feeling of security and willingness to depend on someone or something (Kim et al., 2011). Arguably, the adoption of mobile platforms has fallen short of various service providers' expectations and this might be ascribed to a lack of (initial) trust on the part of several prospective adopters (see Kim et al., 2011; Osakwe, 2013). Moreover, Masinge (2010), among others, suggests users experience with mobile platforms to be correlated with initial trust. In sum, it clearly shows that lack of trust will impede the usefulness and the overall adoption rate of technology-based services like mMoney. As Osakwe (2013) documents, there is a high prevalence of mistrust in the Nigerian society and this itself does not bode well for the greater adoption of mobile financial services like mMoney among the underbanked in the Nigerian society. Taken together, it is expected that PT will play a fundamental role in the Nigerian consumers' positive perception about the perceived usefulness of mMoney.

Perceived Cost Effectiveness (PCE): Recent research is suggestive that lowering transactions cost of MFSs like mMoney is critical for increasing the service perceived usefulness and importantly greater adoption of the service (Chauhan; 2015; Mbogo, 2010; Osakwe, 2013; Upadh- 
yay \& Jahanyan, 2016). Cost factors suggest that perceived relative economic advantages will motivate consumers to use a mobile platform, particularly when it is perceived to lead to a reduction in human errors and labour cost savings at the same time (Gan, Clemes, Limsombunchai, \& Weng, 2006; Sathye, 1999). It has been indicated that for consumers to use technologies, the cost to use technologies need to be reasonable when compared to existing alternatives (see Gan et al., 2006; Sathye, 1999). Although cost is definitely a source of worry for the consumer, especially at the initial stage of any technology adoption, over time it tends to have a less considerable impact on usage of the technology. While Mbogo (2010) found that cost had a significant impact on behavioural intention to use the mobile platform. Research by Masinge (2010) and Lule et al. (2012) also revealed that cost had a significant effect on the adoption of mobile platform on the BoP. A most recent study also finds that cost negatively associates with the adoption of mobile banking services (Chitungo \& Munongo, 2013); although this outcome is consistent with previous research (e.g., Mbogo, 2010; Masinge, 2010), it however conflicts with the findings of Koenig-Lewis, Palmer, and Moll (2010). By and large, it is expected that PCE will play a leading role in the Nigerian consumers' positive perception about the perceived usefulness of mMoney.

Convenience (CVC): Some researchers aver that bank's customers that make use of electronic banking seem to be more attracted to it than other traditional mode of banking due to their beliefs that it is much easier and faster to transact with (e.g., see Karjaluoto, Mattila \& Pento, 2002). A more practical example is the ease of payment of utility bills and remittances transfer through the use of mMoney. Liao and Cheung (2002) as well as Gerrard and Cunningham (2003) also found that the transaction speed (i.e., the perceived speed of response from electronic banking) and the fast access to electronic banking accounts were important attributes for consumers that used electronic banking. Recent practitioners' reports also show that convenience is an important consideration for the use of mMoney service by both users of the service and prospective users (see, Altai Consulting, 2013; Phillips Consulting, 2013). Taken together, it is expected that CVC will play an essential role in the Nigerian consumers' positive perception about the perceived usefulness of mMoney.

Perceived Regulator Assurance (PRA): Doubtless, mMoney is a new development in SSA economies outside Kenya and perhaps Tanzania, and for innovative services like this to succeed; assurances about the safety and benefits of the service will be critical to its success (Osakwe, 2013). This implies strongly that the Nigerian cashless policy, of which mMoney is one of the critical tools conceived to drive this noble policy, will require concrete assurance, notably from these two regulators: CBN and NCC. Accordingly, we opine that one of the most effective ways to convey the benefits of mMoney to its targeted audiences would be through sending strong signals about the security features of the service which might also reinforce trust in the system. Put differently, compelling messages from the regulator(s) will go a long way in reinforcing the commercial messages from the MMOs about the usefulness of the service, and it is expected that it will also significantly help to allay any initial fears about the security of mMoney transactions (see Osakwe, 2013). The fact, also, that there is a growing prevalence of mistrust in the society (Nabareseh et al., 2014; Nabareseh \& Osakwe, 2014), ordinarily, would make prospective users require constant assurances from the concerned authorities. (Particularly at this formative stage of mMoney in Nigeria.) Importantly, in this study, the construct - regulator assurance - is captured by the assurance (i.e., strong messages) the customer receives (constantly) from regulators such as the $\mathrm{CBN}$ and NCC via the mainstream media. To be clear, as far as mMoney service is concerned, $\mathrm{CBN}$ remains the sole regulator while the NCC is expected to play a complementary role (CBN, 2009, 2013a; Osakwe, 2013). Taken together, it is expected that PRA will play a vital role in the Nigerian consumers' positive perception about the perceived usefulness of mMoney.

Phone Network Failure (PNF): By 2009, things had changed since 37.3 out of 100 people were then using mobile phones (The World Bank, 2011). By mid-2014, the penetration rate of the mo- 
bile phone in SSA economies was estimated to be $38 \%$ (GSMA, 2014). Nigeria, with a population of nearly 170 million people, has a huge potential of becoming one of the leading global players within the mobile ecosystem owing to tremendous growth in teledensity within the last twelve years. As mentioned earlier, the country's teledensity as of December, 2015 stood at $107.87 \%$ (NCC, 2016). However, problems of network failure, drop calls, and general poor quality constrain leveraging mMoney adoption through mobile phone. In a study on customers' perception of telecom services in Port Harcourt Nigeria, $60 \%$ of the respondents see the service quality of the industry as (quite) poor while $40 \%$ rated it as good (Hamilton, Nwokah, \& Akpoigbe, 2007). In a study on the critical early adopters' role in early adoption of mMoney in Kenya, Ngugi, Pelowski, and Ogembo (2010) identified system slowdown as among the critical factors affecting adoption of mMoney. Arguably, the poor service quality is even more profound in the rural areas and consequently impedes mMoney adoption among the rural communities. Taken together, it is expected that PNF will play a disturbing role in the Nigerian consumers' perception about the perceived usefulness of mMoney.

Bank Branch Distance (BBD): Nigeria has 24 banks with 5625 branches mostly located in the urban areas (CBN, 2013b). Arguably, the concentration of banks' branches in mainly urban centres is majorly due to the high cost of running banks' branches in rural settlements. (Particularly taking into account that the vast majority of rural dwellers in the country are poor, and as a result their financial transactions are often very low volume in nature.) It could also be contended that since most conventional banks in Nigeria and elsewhere adopt an excessive short-term approach (short-termism) to their balance sheet results, it is not surprising that these traditional institutions are quite reluctant to open shops (i.e., branch offices) in remote areas. (Meanwhile, institutional factors such as road networks, electricity and very poor communications infrastructure also play an integral part.) Interestingly, a recent report by EFinA (2012) is indicative that amongst factors that hinder customers from having a formal bank account is the distance covered to get to a bank branch. Evidently, in the developing world including Nigeria, banks are finding it difficult to open branches in predominantly rural communities or to use traditional channels to service the relatively poorer segments in remote areas (see, Deutsche Gesellschaft für Internationale Zusammenarbeit [GIZ], 2012; Onaolapo \& Odetayo, 2012). Against the background, we see mMoney services as a viable alternative to branch banking that could significantly lower the costs associated with serving this group of customers. All things considered, it is reasonable to expect that the vast majority of the underbanked who as it seems are based in remote locations will find mMoney as a more useful service for their banking needs.

For illustrative purposes, the research model is shown in Figure 1:

\section{Materials and Method}

The research work is based on a usable sample of 127 individual respondents in two major Nigerian cities (Abuja and Lagos). Incontrovertibly, Abuja and Lagos are the two most dominant cities in Nigeria, while Abuja is the current seat of power, Lagos, as the former capital of the country, remains to date the country's financial capital (Osakwe, 2013). The two cities, based on their popularity as well as complexity, are highly multi-cultural as many Nigerians from different parts of the country tend to migrate to these (two) important cities in search for better living conditions and other life opportunities too (see Osakwe, 2013). Ngugi et al. (2010) aver that consumers in such major cities are mostly more educated early adopters as this set of consumers are key for building critical mass (in terms of adoption rate). The authors are not oblivious of the fact that the sample survey does not fully represent the perspectives of all Nigerian consumers' attitude towards mMoney. Data collection was through the use of structured questionnaires; a chunk of the sample was given hard copies of the questionnaire to fill while some selected few were asked to 


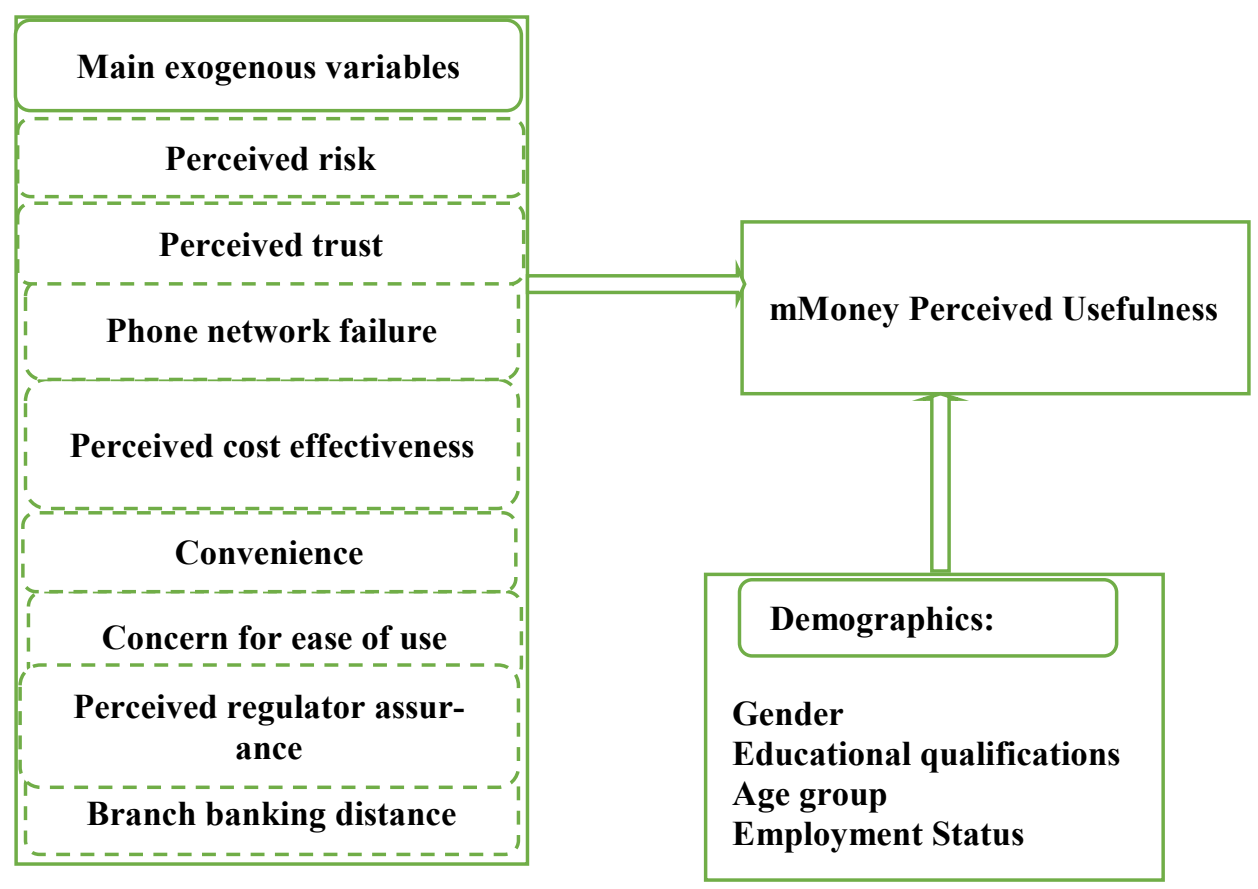

Figure 1. Research Model

fill the questionnaire online which was made possible with the support of Google application (Google Drive). The survey period was within the months of September, 2012 to February, 2013.

For the data analysis, we have used the IBM SPSS Statistics 20 package. Non-parametric statistical techniques were used in analyzing the data. One of such non-parametric statistical methods is Categorical Regression (hereinafter, referred to as CATreg). The CATreg technique offers the possibility of using a non-linear approach to regression technique quite unlike the classical regression model. CATreg uses the method of optimal scaling combined with alternating least squares as well as spline functions to quantify nominal, ordinal, and numeric variables. CATreg offers researchers so many possibilities given that a majority of survey responses is usually either nominal or ordinal in nature and these sorts of data can easily violate some of the key assumptions of the classical regression analysis, hence, the choice of CATreg to investigate the relationship between the perceived usefulness of mMoney and some underlying predictors based on the findings from respondents.

Even though the intercept term is omitted from the final output of the CATreg procedure using SPSS, the wide applicability of the CATreg with optimal scaling technique is not in doubt, especially amongst scholars (see Černá \& Poulová, 2012; Hussain, Castaldi, \& Cholette, 2006; Kooij, 2007; Nabareseh \& Osakwe, 2014; Nováková, Valentová, \& Havlíček, 2014; Xu, Capretz, \& Ho, 2010).

In addition to the CATreg technique for the data analysis, we have also used Kruskal-Wallis test to examine the possibilities of statistical difference across some demographic variables and the dependent variable (perceived usefulness of mMoney). Aside the demographic questions, we have measured our variables of interest on a single Likert scale ranging from least important (1) to extremely important (5), hence the choice of Catreg. The measure for perceived structural assurance was also captured on a single-item scale, ranging from strongly agree to strongly disagree; the variable, branch bank distance, was captured by the estimated time it takes the (potential) customer to get to the nearest bank location (from his/her residential/official residence, ranging from 1-15mins to 1 hour plus). 
It is important to stress here that the theoretical constructs used in this paper tap evidently from the (foundation of the) Technology Acceptance Model (TAM) (see, Davis, 1989) as well as related works on trust and risk factors; we equally introduce into the mMoney adoption equation, new country-specific factors such as phone network failure and branch bank distance.

\section{Results and Discussion}

The sample's profile is as shown in Table 2. The majority of respondents (i.e., $73.2 \%$ ) are yet to make use of mMoney service, whereas most of the respondents (i.e., 83.5\%) have either sent or received airtime (recharge card PIN number) via their mobile phones. The major point to stress from the sample profile (see Table 2) is that sending and/or receiving airtime via the mobile phone is completely different from making use of mMoney application since the former has been in practice for a very long time now by mobile subscribers in the country. Simply put, one does not need to subscribe to mMoney services to send/receive airtime over the phone. mMoney usage should be viewed here as those that have signed up to mMoney services/applications.

Table 2. Sample Profile

\begin{tabular}{ll} 
Captured Variable & Number of Responses \\
\hline Number of Respondents & 127 \\
Gender: & 51 \\
Female & 76 \\
Male & \\
Age Group: & 17 \\
$17-24$ & 60 \\
$25-35$ & 28 \\
$36-45$ & 13 \\
$46-55$ & 9 \\
$56+$ & \\
Employment Status & 51 \\
Public/Private Sector Employee & 43 \\
Self-employed & 21 \\
Student & 3 \\
Unemployed & 8 \\
Pensioner/Retiree & 1 \\
Others & \\
Phone Ownership & 115 \\
Yes, own a Phone & 12 \\
No, does not own a Phone & \\
mMoney Usage & 34 \\
Yes, uses mMoney & 93 \\
No, does not use mMoney & \\
Sent/Receipt of Airtime via Mobile Phone & \\
Yes & 106 \\
No & 21 \\
\hline$\quad$ Source: Authors' computations extracted from SPSS \\
\end{tabular}

The model summary (i.e. F-test with overall fit statistics) is shown in Table 3. Recall, the response variable in this instance is perceived usefulness (PU) of money service while the predictor variables are concerned for ease of use (CFEOU), perceived cost effectiveness (PCE), convenience (CVC), perceived regulator assurance (PRA), perceived trust (PT), perceived risk (PR), phone network failure (PNF), and branch bank distance (BBD). The regression model is statistically significant at the 0.01 level. The pseudo quantified R-Squared value suggests that about 52 percent of the variability of the response variable (PU - perceived usefulness) is accounted for by the predictor variables (see Table 3 ). 
Table 3. Model Summary (F-test with Overall Fit Statistics)

\begin{tabular}{llllll}
\hline & Sum of Squares & Df & Mean Square & F & Sig. \\
\hline Regression & 65.354 & 18 & 3.631 & 6.361 & .000 \\
Residual & 61.646 & 108 & .571 & & \\
Total & 127.000 & 126 & & & \\
& & & & & \\
Multiple R: & \multicolumn{1}{c}{717} & & & & \\
R Square: & .515 & & & & \\
Adjusted R Square: .434 & & & & \\
\multicolumn{5}{c}{ Source: Authors' computations extracted from SPSS }
\end{tabular}

Now, to the main results of the regression analysis (CATreg, Table 4), one of the results of the analysis indicates that perceived cost effectiveness in terms of the affordability of service charge has a positive impact on the perceived usefulness of mMoney, and it is statistically significant at the 0.01 level. This indicates that consumers would consider mMoney useful if the service charge is quite affordable while at the same time providing consumers' value for their money.

Interestingly, another result of the statistical analysis indicates that the construct perceived regulator assurance correlates positively with the perceived usefulness of mMoney; as it is statistically significant at the 0.05 level. Convenience is equally positively related to the perceived usefulness of mMoney, and it is statistically significant at the 0.01 level. Given that mMoney makes it possible for consumers to transact "on-the-go", it is rather not surprising that convenience impacts positively on the perceived usefulness of mMoney.

Also, concerned with ease of use was found to be statistically significant at the 0.01 level and it is inversely related to the perceived usefulness of mMoney. This portends that the more consumers express their worries or concerns over mMoney ease of use, the less they would consider it useful. To put it in another way, concerned for ease of use will inadvertently lead to anxiety and this could invariably take a serious toll on the usefulness of mMoney. It is expected that MMOs would keep the service just like the mobile phone quite simple to use as well as secured.

Table 4. Regression Coefficients Output using CATreg

\begin{tabular}{|c|c|c|c|c|c|c|}
\hline $\mathrm{QV}=\mathrm{PU}$ & \multicolumn{2}{|c|}{ Standardized Coefficients } & $\mathrm{Df}$ & $\mathrm{F}$ & Sig. & Pratt Importance Indicator \\
\hline & \multicolumn{6}{|c|}{ Bootstrap Estimated SE } \\
\hline PCE & .461 & .154 & 3 & 8.956 & $.000 * * *$ & .445 \\
\hline $\mathrm{CVC}$ & .535 & .242 & 2 & 4.878 & $.009 * * *$ & .426 \\
\hline PT & .151 & .206 & 2 & .538 & .586 & 0.099 \\
\hline PR & -.115 & .356 & 1 & .104 & .748 & -0.003 \\
\hline PRA & .214 & .110 & 3 & 3.768 & $.013 * *$ & -0.042 \\
\hline $\mathrm{BBD}$ & .266 & .139 & 2 & 3.645 & $.029 * *$ & .130 \\
\hline PNF & -.167 & .316 & 3 & .280 & .840 & -.019 \\
\hline CFEOU & -.436 & .196 & 2 & 4.962 & $.009 * * *$ & -0.038 \\
\hline
\end{tabular}

The asterisks $(* * *, * *)$ denote statistical significance at the 0.01 and 0.05 levels respectively. Source: Authors' computations extracted from SPSS

Furthermore, with regard to the relationship between branch bank distance and the perceived usefulness of mMoney, the result suggests that the farther away a consumer is from a bank branch, the more (s)he would perceive mMoney as a useful mobile financial service-delivery channel. This finding is indicative that consumers care a lot about bank proximity since it is usually a burden for conventional bank customers in Nigeria to commute from their places of abode to far dis- 
tant bank branches. In contrast, perceived trust, risk, and phone network failure were all found to be statistically insignificant in our regression analysis. Thus, we are unable to provide any empirical evidence on the fifth, sixth and seventh research questions in our current study. In the present study, it is pertinent to point out that in terms of relative importance (Pratt's relative importance indicator) of each individual predictor variable, perceived cost effectiveness (Pratt's score of 0.445) and convenience (Pratt's score of 0.426) appear to be the two most important determinants of perceived usefulness of mMoney.

The reported p-values for the two grouping variables (gender and age group) are 0.481 and 0.232. By reason of brevity, the two tables (output) of Mann-Whitney test used for gender and the Kruskal-Wallis test for the age-group were omitted. However, there is evidence to show that there is a statistically significant difference $(\mathrm{H}(5)=12.037, \mathrm{p}=0.034)$ in the ratings of the perceived usefulness of mMoney across the six levels of employment status (see Table 5). The effect size using eta-squared $(\eta 2)$ gives an approximate value of 0.10 . The eta-squared value indicates the variance of the response variable (perceived usefulness) that is accounted for by the grouping variable (in this case - employment status). Based on this finding, we can conclude that there is a moderate effect size between mMoney perceived usefulness and employment status.

Table 5. Result of Kruskal-Wallis Test

\begin{tabular}{|c|c|c|}
\hline & Employment Status & N Mean Rank \\
\hline & Public/Private Sector Employee & e51 70.24 \\
\hline & Self-employed & 4354.71 \\
\hline & Student & 2157.81 \\
\hline Perceived Usefulness & sUnemployed & 3100.00 \\
\hline & Pensioner/Retired & $8 \quad 80.56$ \\
\hline & Others & 135.00 \\
\hline & Total & 127 \\
\hline \multicolumn{3}{|l|}{ Test Statistics $^{\text {a,b }}$} \\
\hline \multicolumn{3}{|c|}{ Perceived Usefulness } \\
\hline Chi-Square & 12.037 & \\
\hline Df & 5 & \\
\hline Asymp. Sig. & .034 & \\
\hline Grouping Variable: E & Employment Status & \\
\hline
\end{tabular}

Source: Authors' computations extracted from SPSS

Further results appear to indicate that there is no statistical significance difference between the ratings of the perceived usefulness of mMoney across gender as well as age group. Apparently, the unemployed with a mean rank of 100 seem to indicate that mMoney is very a useful service for this group of people. Arguably, the unemployed do not supposedly have formal bank accounts, hence, the higher ratings of the perceived usefulness of mMoney to this particular segment. Next in line to higher ratings of the perceived usefulness of mMoney are those who are pensioners or retirees. It is most likely the higher ratings of the perceived usefulness of mMoney from the two groups could be attributable to the convenience of the service.

\section{Summary and Conclusion}

In this paper, our major objective was to explore the relationship that potentially exists between the construct of perceived usefulness of mMoney services and important factors such as perceived cost effectiveness (affordability), convenience, branch bank distance, concern for ease of use, phone network failure, perceived trust, perceived risk as well as perceived regulator assurance in the Nigerian context. For the most part, results of the preliminary analysis support prior research in the broader field of mCommerce including works on MFS. 
For example, in a most recent fact finding report by Altai Consulting (2013), the report says, particularly in the Afghanistan mMoney context, that due to the perceived belief that the service might not be so easy to operate and/or use especially by its targeted audiences (who are more or less relatively uneducated); it significantly affects the usefulness of the service and ultimately its adoption rate. The preliminary finding in this paper that worry over ease of use negatively associates with perceived usefulness of the service is in tandem with the reported findings of Altai Consulting (2013). Put differently, perceived ease of use of mMoney is a significant predictor of the service's perceived usefulness, and the result offers preliminary empirical support for prior related research (see Chauhan, 2015; Dass \& Pal, 2011; Peng, Xiong, \& Yang, 2012; Tobbin, 2010).

Similarly, the preliminary evidence is indicative that perceived cost effectiveness, that is affordability, relates significantly to perceived usefulness of mMoney service. In many respects, it complements previous findings about the relationship between service cost implications and perceived usefulness of mCommerce in general (for instance, see Cho, 2008). Relatedly, in an early study by Järveläinen (2004) which covers the much broader field of B2C eCommerce, the author finds that cost effectiveness in terms of money saving is a fundamental underlying dimension of the construct of perceived usefulness; the result of this work certainly complements the initial work of Järveläinen.

The preliminary finding also that convenience is a strong predictor of perceived usefulness of mMoney lends empirical support for Cho (2008) who reports that convenience is an important consideration for the perceived usefulness of mCommerce activities in both the US and Korean contexts. Interestingly, the preliminary evidence about the potential strong connection between convenience and perceived usefulness of mMoney is equally hinted in two recent country-wide mMoney reports by Altai Consulting (2013) and Phillips Consulting (2013) in Afghanistan and Nigeria, respectively.

Interestingly too, the belief in the financial inclusion literature including MFS research that those who live in remote areas and/or less-urbanized areas with little or no presence of formal banking institutions will be more likely to embrace MFS like mMoney service holds true in this preliminary empirical report (also see Castri, 2013; Mas \& Radcliffe, 2011; Osakwe, 2013; Upadhyay \& Jahanyan, 2016). What is more, this preliminary finding is unique in the literature, particularly as it is arguably the first to test and report the correlation between (branch) bank distance and perceived usefulness of mMoney. For sure, this preliminary result warrants further empirical investigation in order that it might help us establish concrete evidence about the relationship.

The other important finding of this preliminary study suggests that assurances from the Nigerian regulators including $\mathrm{CBN}$ and NCC will to a certain degree increase the greater perceived usefulness of mMoney among its targeted users. Given that regulator assurance is certainly an integral aspect of the broader concept of structural assurance and/or the underlying mechanism of institutional-based trust, the finding mirrors previous research which reports about the critical role that structural assurance including perceived regulator assurance plays in communicating effectively the greater perceived usefulness of mobile innovative services such as mMoney while also at the same time helping strongly in building a critical mass for greater adoption, too (among others, see Cousins \& Varshney, 2014; Upadhyay \& Jahanyan, 2016).

That said, our preliminary analysis could not establish any form of tangible evidence between perceived trust, perceived risk, phone network failure, and perceived usefulness of mMoney service. This certainly calls for more rigorous research in this realm and elsewhere. We shall certainly revisit the call for further research in the subsequent section of this paper.

By and large, the success of mMoney as a tool for driving mCommerce growth as well as financial inclusion for the hitherto unbanked populace who are predominantly members of the BoP 
segment hinges largely on the availability of credible agents, a solid understanding of consumers' needs, as well as meaningful collaboration among the critical stakeholders.

We also posit that for mMoney to actually thrive in the SSA region, particularly Nigeria, it must be mobile as the name suggests. For instance, agents would have to be positioned in every nook and cranny of the six geopolitical zones in the country. The agents are expected to be highly proactive in order to meet the numerous needs of consumers. The key theme here remains agents' visibility and the results of the preliminary study support this assertion given that individuals who live very far from a bank branch are more likely to see the attendant benefits in mMoney compared to those who live within a short distance of formal bank branches. On a practical note, it is suggested that MMOs team up with credible street vendors, these street vendors could act as agents. It is more likely that increasing network of credible agents could trigger the adoption of mMoney by the BoP segment. The possible network effect emanating from such an adoption by the unbanked could scale up financial inclusion in the country and in tandem open up the mCommerce landscape. This is highly likely to cause disruptive innovation within the retail businesses in Nigeria. The authors are equally of the opinion that the concerned regulatory agencies in Nigeria alongside the MMOs must continually strive to make the average Nigerian consumer see the perceived usefulness of mMoney service. This also calls for more 'localized' awareness creation with respect to the education of early adopters and non-adopters about the benefits and security features of mMoney.

Sensitization campaigns with a focus on educating the masses about the benefits of the service and, importantly, the security features of the service will certainly go a long way in building confidence in the system. Such media campaigns ought to be taken to local communities via the use of radio, billboards, TV ads, newspaper campaigns, and informal channels such as town-hall meetings and market storm in open markets across various local communities. MMOs should equally take advantage of social media sites given that the majority of Nigerian youths are very much involved in most of the notable social network sites (SNS). Such social media campaigns by MMOs must be seen as engaging and empowering for the campaigns to have their desirable effect on its targeted audiences.

Again, to recapitulate, it is expected that the Nigerian regulators in the mMoney ecosystem will constantly assure Nigerians, particularly the underbanked populace, about the security-proof of the service as well as its attendant benefits. Our result has demonstrated the critical role that perceived regulator assurance can play in reinforcing perceived usefulness of mMoney and ultimately the potential adoption of the service too. Meanwhile, with regard to the low level of culture of trust in Nigeria as well as similar Anglophone countries (cf. comments by Nabareseh et al., 2014; Nabareseh \& Osakwe, 2014), targeted media campaigns about how secured mMoney transactions are would certainly go a long way in allaying fears from the minds of its prospective users. At the same time, it is expected that such compelling and strong campaigns would significantly help to build the much needed trust between service providers and targeted users. Another fundamental area that MMOs and the regulatory body should pay close attention to is transaction fees; the result of the (preliminary) empirical work has shown that affordability is positively associated with perceived usefulness. More so, the BoP populace by default is a price conscious segment given their low incomes (see Osakwe, 2013). Thus, the finding that perceived cost effectiveness, i.e., affordability, positively relates to mMoney perceived usefulness is suggestive that charging users of the service outrageous service fees could be detrimental to the success of mMoney in Nigeria and elsewhere.

To also add (though certainly not so far from the study's investigation) to the paper, an area that needs to be continuously addressed is the issue of shortage of available cash (float) among agents. This particular issue breeds 'badmouthing' of the service and invariably erodes consumers' confidence in the system, and it further leads to customer attrition. Therefore, a deeper understanding 
of mMoney users' behaviour will certainly go a long way in positioning mMoney as a viable alternative channel in the minds of its targeted users (especially, the BoP segment). At the same time, MMOs should be prepared to tweak some of their existing business models giving the dynamics of this segment. It must be underscored that delivering financial services to the BoP demands the provision of affordable services for this unique segment of the population. Also, service providers must be seen as trustworthy and equally empowering in the long run.

Consequently, we would expect that in the long run, the Nigerian apex bank would allow MMOs to offer credit facilities to their customers, no matter how small the loan would be. This is one vital area that could be possibly explored by some of the innovative MMOs within the mediumterm since it is vital for MMOs in collaboration with CBN to deepen mMoney service beyond transfers and cash receipts. One area we would not fail to give kudos to the regulatory authority $(\mathrm{CBN})$ is the implementation of interoperability of the mMoney platforms via the National Central Switch (NCS) operated by the Nigeria Inter-Bank Settlement System -NIBSS (Nigeria Communications Week, 2013). This would definitely go a long way in offering convenience to consumers while at the same time seamlessly integrating financial inclusion and mCommerce.

All things considered, the study's preliminary analysis meaningfully helps shed a light on some of the important factors that are currently shaping consumers' perceptions of the usefulness of mMoney services in Nigeria, particularly in the country's most influential cities - Abuja and Lagos. The research has in part also theoretically added to the emerging mMoney adoption literature through the consideration of significant factors such as the service affordability, concern for ease of use, convenience, perceived regulator assurance and branch bank distance, not also forgetting the role of customers' demographics on the perceived benefits/usefulness of mMoney. In terms of practical contribution, the study has demonstrated the role that regulatory bodies can play through the enhancement of structural assurance, and this is considered to play an instrumental part to perceived usefulness of mMoney services.

Overall, the study's preliminary findings may help inform practitioner's knowledge as well as policymaking (on the part of the regulator(s)) about the major factors impacting the general perception about mMoney in the Nigerian context. Notably, our argumentation is that gains in mMoney usage and its (perceived) attendant benefits will go a long way in entrenching the culture of mobile business activities, thereby spurring mCommerce growth in Nigeria and similar emerging powers. Doubtless, mMoney is still at its rudimentary stage in Nigeria; hence it calls for more solid collaboration amongst all its critical stakeholders. One would be careful to point out at this juncture that mMoney is not a panacea for either financial inclusion or mCommerce growth in the SSA region but if the potentials in it are well harnessed by all the stakeholders, most importantly MMOs, agents, and the regulatory authorities; mMoney could fill the vacuum created between the less developed financial system of SSA economies and the region's mCommerce landscape.

\section{Limitations and Direction of Future Research}

Similar to most survey studies and related research works, the present study has some obvious limitations. First, among others is the limited sample size; the sample size cannot be fully described as being representative of the target population. Thus, in actual sense, the study's findings cannot be fully generalized to all geopolitical zones within the Nigerian nation. Accordingly, the interpretation and generalization of the study results should be treated with caution.

Moreover, the study design does not take into account the changing dynamics of consumer behaviour over time given that this kind of unique information could only have been gotten from a longitudinal study. Similarly, the single-item Likert scale used in the questionnaire might not have fully captured the constructs and their relationships. Anyway, the justification for using this 
type of measurement had to do with the statistical method that was initially thought of prior to conducting the survey as well as the need to keep the questionnaire items relatively few at this preliminary stage of (our) research.

Notwithstanding the highlighted shortcomings of the current study, the obtained empirical evidence from the present study cannot be watered-down since the results are indeed revealing. This study serves as a reference point for future works given that this is arguably the first study of its kind to explore empirically consumers' attitude towards the perceived usefulness of mMoney (from a Nigerian standpoint). A replication of this study with a much larger and representative sampling would go a long way in gaining a better understanding of the consumers' perspective(s) on mMoney in Nigeria. It would also be interesting to see further research with a focus on understanding institutional and cultural factors that are potentially limiting the uptake of mMoney usage in rural Nigeria.

Another important area future studies may want to look into carefully is the fee-based structure of mMoney transactions given that the target market (BoP segment) is a 'highly' price-sensitive segment. In similar lines, a comparative analysis of the adoption level of mMoney services across two SSA countries (e.g., Nigeria and Tanzania) would to a certain extent further our understanding of consumer behaviour with regard to the breadth of usage of mMoney as well as its pivotal role in promoting and integrating the hitherto informal sector with the formal sector in SSA economies. Moreover, future research should consider having micro-sized to small-sized firms' view of the scope of usage of mobile services in connection with mCommerce in some selected SSA economies. We opine that the SSA region cannot longer afford to remain backward in the present-day technologically driven cum financially-integrated globalized community. Therefore, a research approach that encompasses all the stakeholders of the digitally-enabled financial ecosystem would go a long way in solidifying the insights shed in this paper. At the same time, it is hoped that further research in this area will articulate a much clearer and comprehensive roadmap on what should be effectively done by SSA economies including Nigeria to catch up with other emerging markets and possibly the advanced economies as far as the mCommerce space is concerned.

Overall, this work represents an original contribution to the current state of affairs of both financial inclusion and mCommerce developments in Nigeria. In a nutshell, the salient point to make here is that a number of factors such as affordability of the service, convenience, perceived regulator assurance, proximity to the nearest bank branch, and worry over ease of use have been found to significantly impact consumers' perceived usefulness of mMoney in the Nigerian case (using survey data from its two most prominent cities, i.e., Abuja and Lagos). Categorical regression (CATreg) and Kruskal Wallis tests were employed in analyzing the data. Needless to say, this is one of the first papers in the country to address this issue of current interest among practitioners and developmental institutions. For now, the factors that have been revealed in this preliminary analysis to be plausible explanations for the perceived usefulness of mMoney (and perhaps its eventual greater adoption rate) certainly requires further research.

\section{Acknowledgement and Declaration of Interest}

The authors are indebted to Vaclav Lohr (PhD), Mohammed Mamman (Ing), Chukwudi Nwaogu (Ing.) and Ekene Eziagulu (BSc) for their initial support. The first author is also grateful to FAME for the support, especially with respect to the Internal Grant Agency of FaME TBU No.: IGA/FAME/2015/039. The authors are so grateful to the Journal's editorial team, including Prof. Eli Cohen, Dr. Maureen Tanner, Elizabeth Boyd, and the reviewers for their constructive guidance. This paper certainly draws inspiration from the first author's unpublished Master's thesis. 


\section{References}

Adesina, A. A., \& Ayo, C. K. (2010). An empirical investigation of the level of users acceptance of ebanking in Nigeria. Journal of Internet Banking and Commerce, 15(1), 1-13.

Aker, J. C., \& Mbiti, I. M. (2010). Mobile phones and economic development in Africa. Journal of Economic Perspectives, 24(3), 207-232.

Altai Consulting (2013). Market research on mobile money in Afghanistan. Retrieved from http://www.altaiconsulting.com/application/views/images/media/pdf/Altai\%20MR\%20Mobile\%20Mo ney\%20FINAL.pdf

Ayo, C. K., Ekong, U. O., Fatudimu, I.T., \& Adebiyi, A. A. (2007). M-commerce implementation in Nigeria: Trends and issues. Journal of Internet Banking, 12(2), 1-15.

Bang, Y., Han, K., Animesh, A., \& Hwang, M. (2013). From online to mobile: Linking consumers' online purchase behaviors with mobile commerce adoption. PACIS 2013 Proceedings, Paper 128. Retrieved from http://aisel.aisnet.org/pacis2013/128

Boadi, R. A., Boateng, R., Hinson, R., \& Opoku, R. A. (2007) Preliminary insights into m-commerce adoption in Ghana. Information Development, 23(4), 253-265.

Boateng R (2011). Mobile phones and micro-trading activities-conceptualizing the link. Info: The Journal for Policy, Regulation and Strategy, 13(5), 48-62.

Boateng, R., Hinson, R., Galadima, R., \& Olumide, L. (2014). Preliminary insights into the influence of mobile phones in micro-trading activities of market women in Nigeria. Information Development, $30(1), 32-50$.

Cao, Y., Lu, Y., Gupta, S., \& Yang, S. (2015). The effects of differences between e-commerce and mcommerce on the consumers' usage transfer from online to mobile channel. International Journal of Mobile Communications, 13(1), 51-70.

Camner, G. (2013). Reading the M-PESA half-year results for 2013-2014, Mobile money for the unbanked, GSMA. Retrieved 19032014 from http://www.gsma.com/mobilefordevelopment/reading-the-m-pesahalf-year-results-for-2013-2014

Castri, S. D. (2013). Mobile money: Enabling regulatory solutions. GSMA - Mobile money for the unbanked. Retrieved 19032014 from http://www.gsma.com/mobilefordevelopment/wpcontent/uploads/2013/02/MMU-Enabling-Regulatory-Solutions-di-Castri-2013.pdf

Central Bank of Nigeria (CBN). (2009). Regulatory framework for mobile payments services for mobile payments services in Nigeria. Retrieved 18032014 from http://www.cenbank.org/out/circulars/bod/2009/regulatory\%20framework\%20\%20for\%20mobile $\% 20$ payments $\% 20$ services $\% 20$ in $\% 20$ nigeria.pdF

Central Bank of Nigeria (CBN). (2012). Towards a cashless Nigeria: Tools and strategies. CBN Presentation at the 24th National Conference of Nigeria Computer Society held at Uyo, Nigeria., 25-27 July. Retrieved 16032014 from http://www.NCS.org/presentations/

Central Bank of Nigeria (CBN). (2013). Mobile money and telco regulation in Nigeria. International Conference on Payments System. Retrieved 17032014 from http://www.cbn.gov.ng/icps2013/papers/Mobile\%20Money\%20and\%20Telcos\%20Regulation.pptx

Central Bank of Nigeria (CBN). (2016). Statistics Database [Online]. Retrieved 28052016 from http://statistics.cbn.gov.ng/cbn-onlinestats/QueryResultWizard.aspx

Černá, M., \& Poulová, P. (2012). Social software applications and their role in the process of education from the perspective of university students. The Proceedings of the 11th European Conference on eLearning, University of Groningen, The Netherlands. Retrieved from http://academicconferences.org/pdfs/BU_2012-13-Nov/ECEL_2012-Abstract-booklet.pdf

Chauhan, S. (2015). Acceptance of mobile money by poor citizens of India: Integrating trust into the technology acceptance model. Info, 17(3), 55-68. 
Chitungo, S. K., \& Munongo, S. (2013). Extending the technology acceptance model to mobile banking adoption in rural Zimbabwe. Journal of Business Administration and Education, 3(1), 51-79.

Cho, C. Y. (2008). Assessing user attitudes toward mobile commerce in the U.S. Vs. Korea: Implications for M-Commerce CRM. Journal of Business \& Economics Research, 6(2), 91-102.

Cobert, B., Helms, B., \& Parker, D. (2012). Mobile money: Getting to scale in emerging markets. McKinsey Publication (February). Retrieved from http://www.mckinsey.com/industries/social-sector/ourinsights/mobile-money-getting-to-scale-in-emerging-markets

Cousins, K. D., \& Varshney, U. (2014). The regulatory issues affecting mobile financial systems: Promises, challenges, and a research agenda. Communications of the Association for Information Systems, 34(Article 76), 1457-1480.

Dass, R., \& Pal, S. (2011). A meta analysis on adoption of mobile financial services. W.P. No. 2011-01-05, Indian Institute of Management, Ahmedabad. Retrieved from http://www.iimahd.ernet.in/assets/snippets/workingpaperpdf/2011-01-05Rajanish.pdf

Davis, F. D. (1989). Perceived usefulness, perceived ease of use, and user acceptance of information technology. MIS Quarterly, 13(3), 319-340.

Davis, F. D., Bagozzi, R. P., \& Warshaw, P. R. (1989). User acceptance of computer technology: A comparison of two theoretical models. Management Science, 35(8), 982-1003.

Demirguc-Kunt, A., \& Klapper, L. (2012). Measuring financial inclusion: The global findex database. Policy Research Working Paper, 6025, The World Bank, Washington, DC. Retrieved 14122012 from http://elibrary.worldbank.org/doi/pdf/10.1596/1813-9450-6025

Deutsche Gesellschaft für Internationale Zusammenarbeit (GIZ). (2012). Financial services for rural areas agent banking - Mobile money - Linkage banking. Conference Summary \& Key Findings, 28 - 29 October, Maputo, Mozambique. Retrieved from https://www.giz.de/en/downloads/giz2014-enconference-summary-key-findings-maputo.pdf

Ebiye, E. V. (2015). Impact of smartphonestablets on the information seeking behaviour of medical students and staff of Niger Delta University Bayelsa State - Nigeria. Library Philosophy and Practice (ejournal), Paper 1288. http://digitalcommons.unl.edu/libphilprac/1288

EFInA. (2012). Efina access to financial services in Nigeria 2012 survey: Key findings. Retrieved from http://www.efina.org.ng/assets/ResearchDocuments/2013-Documents/EFInA-Access-to-FinancialServices-in-Nigeria-2012-surveyKey-Findings2.pdf

Egbuta, O. C. (2013). Mobile money technology and the quest for a cashless Nigeria. Asian Transactions on Science \& Technology, 3(2), 1-5.

Fishbein, M., \& Ajzen I., (1975). Belief, attitude, intention and behaviour: Introduction to theory and research. Reading, MA: Addison-Wesley.

Gan, C; Clemes, M., Limsombunchai, V., \& Weng, A. (2006). A logit analysis of electronic banking in New Zealand. International Journal of Bank Marketing, 24(6), 360 - 383.

Garcia-Murillo, M. (2003). Patchwork adoption of ICTs in Latin America. EJISDC, 15(1), 1-9.

Gerrard, P., \& Cunningham, J. B. (2003). The diffusion of internet banking among Singapore consumers. International Journal of Bank Marketing, 21(1), 16-28.

GSMA. (2013a). Sub-Saharan Africa mobile economy 2013. Retrieved 15022014 from http://www.gsmamobileeconomyafrica.com/SubSaharan\%20Africa_ME_ReportEnglish_2013.pdf

GSMA. (2013b). Mobile financial services for the unbanked, State of the industry 2013. Retrieved 12032014 from http://www.gsma.com/mobilefordevelopment/wp- content/uploads/2014/02/SOTIR 2013.pdf

GSMA. (2014). The mobile economy 2014: Sub-Saharan Africa. Retrieved from http://www.gsmamobileeconomyafrica.com/GSMA_ME_SubSaharanAfrica_Web_Singles.pdf 
GSMA Mobile Money Tracker. (2014). Mobile money tracker. Retrieved from http://www.mobileworldlive.com/mobile-money-tracker

Hallmark Newspaper. (2013). Mobile money transactions rise to N74.2bn - CBN. Retrieved 20032014 from http://www.hallmarknews.com/mobile-money-transactions-rise-to-n74-2bn-cbn/

Hamilton, D. I., Nwokah, G. N., \& Akpoigbe, E. O. (2007). Customer perception of telecommunication services: A comparative study of major GSM service providers in Port Harcourt. Nigerian Journal of Entrepreneurship and Enterprise Management, 18-25.

Hussain, M., Castaldi, R., \& Cholette, S. (2006). Determinants of wine consumption of U.S. consumers: An econometric analysis. 3rd International Wine Business Research Conference, Montpellier. Retrieved from http://www.wineecoreports.com/upload/internet/HUSSAIN_CASTATLDI_CHOLETTE_Determinant s_of_Wine_Consumption_of_US_Consumers.pdf

ITU. (1998). Methodological note on the choice of teledensity bands. International Telecommunication Union (ITU) Report. Retrieved 20012014 from https://www.itu.int/osg/spu/intset/focus/bands.pdf

Järveläinen, J. (2004). Perceived usefulness and ease-of-use items in B2C electronic commerce. In W. Lamersdorf, V. Tschammer, \& S. Amarger (Eds.), Building the e-service society (pp. 475-489). New York City, US: Springer.

Karjaluoto, H., Mattila, M., \& Pento, T. (2002). Electronic banking in Finland: Consumer beliefs and reactions to a new delivery channel. Journal of Financial Service Marketing, 6, 346-361.

Kim, M.-J., Chung, N., \& Lee, C.-K. (2011). The effect of perceived trust on electronic commerce: Shopping online for tourism products and services in South Korea. Tourism Management, 32(2), 256-265.

Koenig-Lewis, N., Palmer, A., \& Moll, A. (2010). Predicting young consumers' take up of mobile banking services. International Journal of Bank Marketing, 28(5), 410-432.

Kooij, A. J. van der. (2007). Prediction accuracy and stability of regression with optimal scaling transformations. Unpublished doctoral thesis, Leiden University. Retrieved from https://openaccess.leidenuniv.nl/handle/1887/12096

Laroche, M., McDougall, G. H. G., Bergeron, J., \& Yang, Z. (2004). Exploring how intangibility affects perceived risk. Journal of Service Research, 6(4), 373-389.

Liao, Z., \& Cheung, M. T. (2002). Internet based e-banking and consumer attitudes: An empirical study. Information \& Management, 39, 283-295.

Lule, I., Omwansa, T. K., \& Waema, T. M. (2012). Application of technology acceptance model (TAM) in m-banking adoption in Kenya. International Journal of Computing and ICT Research, 6(1), 31-43.

Mas, I., \& Radcliffe, D. (2011). Mobile payments go viral: M-PESA in Kenya. The Capco Institute Journal of Financial Transformation, 32, 169-182.

Masinge, K. (2010). Factors influencing the adoption of mobile banking services at the bottom of the pyramid in South Africa. Master's Thesis, Gordon Institute of Business Science, University of Pretoria, Pretoria. Retrieved from http://repository.up.ac.za/xmlui/bitstream/handle/2263/24694/dissertation.pdf? sequence=1\&isAllowed $=\mathrm{y}$

Mbarika, V. W. A., Okoli, C., Byrd, T. A., \& Datta, P. (2005). The neglected continent of IS research: A research agenda for Sub-Saharan Africa. Journal of the Association for Information Systems, 6(5), 130170.

Mbogo, M. (2010). The Impact of Mobile Payments on the Success and Growth of Micro-Business: The case of M-Pesa in Kenya. The Journal of Language, Technology \& Entrepreneurship in Africa, 2(1), 182-203.

MEF. (2014). Mobile payments driving mCommerce adoption. Retrieved from http://www.mefmobile.org/News/mef-news/235/mobile-money-report 
Mendelson, S. (2012). Who are the clients for financial services in low and middle-income countries - and how do we identify their needs over their financial life-cycles? DFID/CITI CSFI Development Fellowship, Working Group1. Retrieved 19032014 from http://www.csfi.org/files/Fellowship_WG_1_Draft_Report_11_6_12.pdf

Michael, E. C., Chinwokwu, E. C., \& Arop, S. K. (2014). Subscribers' perception of SIM card retrieval: Implications on criminality and behaviour in Calabar Municipality, Cross River State. Mediterranean Journal of Social Sciences, 5(10), 620-629.

Mitchell, V.-W., \& Greatorex, M. (1993). Risk perception and reduction in the purchase of consumer services. The Service Industries Journal, 13(4), 179-200.

Mitra, K., Reiss, M. C., \& Capella, L. M. (1999). An examination of perceived risk, information search and behavioral intentions in search, experience and credence services. Journal of Services Marketing, 13(3), 208-228.

Morgan, J., \& Ravindran, S. (2014). An examination of home internet and mobile device use in the U.S. Interdisciplinary Journal of Information, Knowledge, and Management, 9, 1-18. Retrieved from http://www.ijikm.org/Volume9/IJIKMv9p001-018Morgan0472

Nabareseh, S., \& Osakwe, N.C. (2014). Can Business-to-Consumer Electronic Commerce Be a GameChanger in Anglophone West African Countries? Insights from Secondary Data and Consumers' Perspectives. World Applied Sciences Journal, 30(11), 1515-1525.

Nabareseh, S., Osakwe, C. N., Klimek, P., \& Chovancova, M. (2014). A comparative study of consumers' readiness for internet shopping in two African emerging economies: Some preliminary Findings. Mediterranean Journal of Social Sciences, 5(23), 1882-1889.

National Bureau Statistics [NBS]. (2014). General household panel survey, Wave 2 2012/2013 in collaboration with the World Bank Living Standards Measurement Study Group. Retrieved from http://www.nigerianstat.gov.ng/pages/download/195

Ngugi, B., Pelowski, M., \& Ogembo, J. G. (2010). M-PESA: A case study of the critical early adopters' role in the rapid adoption of mobile money banking in Kenya. The Electronic Journal of Information Systems in Developing Countries (EJISDC), 43(3), 1-16.

Nigerian Communication Commission [NCC]. (2016). Annual subscriber data (2001-2015). Retrieved 20022016 from http://ncc.gov.ng/index.php?option=com_content\&view=article\&id=125\&Itemid=73

Nigeria Communications Week. (2013). NIBSS begins interoperability services in mobile money transactions. Retrieved 24032014 from http://www.nigeriacommunicationsweek.com.ng/node/5297\#sthash.Fo824P5F.dpuf

NOIPolls. (2013). Mobile money services snap poll, conducted in the week of 5th August 2013. Retrieved from http://www.noi-polls.com/index.php?s_id=3\&p_id=259\&p_pt=1\&parent=8\#.UyoZV87iiHg

Nováková, L., Valentová, J. V., \& Havlíček, J. (2014). Correction: Olfactory performance is predicted by individual sex-atypicality, but not sexual orientation. PLoS ONE, 9(1), 1-10.

Okeke, T. C. (2013). Perceived risk/security and consumer involvement with electronic payments in Nigeria: A discriminant analysis. IOSR Journal of Business and Management, 14(6), 57-67.

Olayinka, D.-W. (2016). The path to digital financial inclusion in Nigeria: Experiences of Firstmonie. Journal of Payments Strategy \& Systems, WINTER (2015-16), 256-273.

Onaolapo, A. A., \& Odetayo, T. A. (2012). Financial inclusion as tools for survival in globally competitive environment: Lessons for Nigerian microfinance banks. American Journal of Business and Management, 1(4), 241-247.

Osakwe, N. C. (2013). Transformational mBanking in emerging markets: A case study of mMoney in Nigeria. Unpublished Master's Thesis, Czech University of Life Sciences, Prague.

Paga. (2014). Paga achieves one million users. Retrieved from https://www.mypaga.com/pagaweb/start.paga\# 
Peng, R., Xiong, L., \& Yang, Z. (2012). Exploring tourist adoption of tourism mobile payment: An empirical analysis. Journal of Theoretical and Applied Electronic Commerce Research, 7(1), 21-33.

Phillips Consulting. (2013). Current trends in mobile money in Nigeria. Mobile money report. Retrieved from http://www.phillipsconsulting.net/files/mobile-money-report2013.pdf

Riquelme, H. E., \& Rios, R. E. (2010). The moderating effect of gender in the adoption of mobile banking. International Journal of Bank Marketing. 28(5), 328-341.

Rusu, R. F., \& Shen, K. N. (2012). An empirical study on e-banking acceptance in the United Arab Emirates (UAE). Journal of Electronic Banking Systems, 2012, 1- 9. DOI: 10.5171/2012.462904

RTC Advisory Services Ltd. (2013). Electronic payments and economic growth in Nigeria. Retrieved from http://www.proshareng.com/admin/upload/reports/RTCcashless.pdf

Sathye, M. (1999). Adoption of internet banking by Australian consumers: An empirical investigation, The International Journal of Bank Marketing, 17(7), 324-334.

The World Bank. (2011). The little data book on information and communication technology. Washington D.C., USA.

Tobbin, P. E. (2010). Modeling adoption of mobile money transfer: A consumer behaviour analysis. Paper presented at The 2nd International Conference on Mobile Communication Technology for Development, Kampala, Uganda. Retrieved from http://vbn.aau.dk/files/43733959/TOBBIN_paper_m4d_1.pdf

Upadhyay, P., \& Jahanyan, S. (2016). Analyzing user perspective on the factors affecting use intention of mobile based transfer payment. Internet Research, 26(1), 38-56.

VantageB2B. (2014). Mobile eCommerce payments to reach $\$ 117$ billion globally by 2017. Retrieved 16032014 from http://www.vantageb2b.com/blog/study-mobile-ecommerce-payments-to-reach-117billion-globally-by-2017\#.Uyd-36iHwrU

Xu, J., Capretz, L. F., \& Ho, D. (2010). Building an OSS quality estimation model with CATREG. International Journal on Computer Science and Engineering, 2(6), 1952-1958.

Zeithaml, V, A. (1981). How consumer evaluation process differ between goods and services. In J. H. Donnelly \& W. R. George (Eds.), Marketing of Service, Proceedings Series of the American Marketing Association. 


\section{Appendix: Abridged Research Instrument}

1 . Which category below includes your age? *

$17-24$ years

25-35 years

$36-45$ years

46-55 years

56 years and above

2. Gender *

Male

Female

3. Which of the following best describes your current occupational status? *

Government/Private Sector Employee

Self-Employed

Student

Unemployed

Pensioner/Retired

Others

4. Do you have a mobile phone? *

Yes

No

5. Do you have a bank account? *

Yes

No

6. If 'NO' to the previous question. Would you like to open a bank account using your mobile phone?

Yes

Maybe

No

7.Which two activities do you normally do most with your handset (mobile phone)?

Making/receiving calls and SMS

Making/receiving calls and Web(INTERNET) browsing

Making/receiving calls and Others

SMS and Web(INTERNET) browsing

SMS and Others

8. What is the average time, it takes to get to the nearest bank branch from your house or place of work? * $1-15 \mathrm{mins}$

16-35mins

36-59mins

I hour or more

9. Have you ever sent or receive airtime (recharge card) on your handset? *

Yes

No

10. How do you usually send or receive money from others? *

Cash (sent via bus or someone else)

Bank

Mobile Money Transfer

Others 
11. Are you aware of mobile money? *some mobile money operators include Pagatech,EcoCash,GTMobile Money,UBA/U-Mo,eTranzact,Fortis Mobile Money,etc

Yes

No

12. If 'Yes' to the previous question, through which medium? How did u hear about mobile money? You can tick more than one option.

Word of Mouth

TV/Radio

Billboard

INTERNET/Social Media Sites

Newspapers/Magazines

Community Meetings

Others

13. Have you ever used or do you currently use any mobile money service? using your mobile phone for money transfer, buying of airtime, paying of utility bills, savings, merchant payments, etc.

Yes

No

14. If 'Yes', please state which mobile money service(s) you have used.-money transfer, buying of airtime, paying of utility bills(DSTV,PHCN,WATER BOARD, etc.), savings, merchant payments, etc.

15. Have you ever seen any mobile money agent office/shop within your neighbourhood or place of work? *

Yes, I have

Not so sure

No, I have not

16. Which factors do you think are the most important to you in the adoption of MOBILE MONEY? ${ }^{*}$ Rank the following choices (1 - Least Important to 5 -Extremely Important)

$\begin{array}{lllll}1 & 2 & 3 & 4 & 5\end{array}$

Perceived Trust

Perceived Risk (i.e., Security

Concern)

Phone Network/Technology Failure

Perceived Usefulness

Perceived Cost Effectiveness

(i.e., Affordability)

Convenience

Concern for Perceived Ease of Use

17. I would be interested in using mobile money services if I get assurances from CBN and NCC? * Strongly Agree

Agree

Unsure

Disagree

Strongly Disagree 


\section{Biographies}

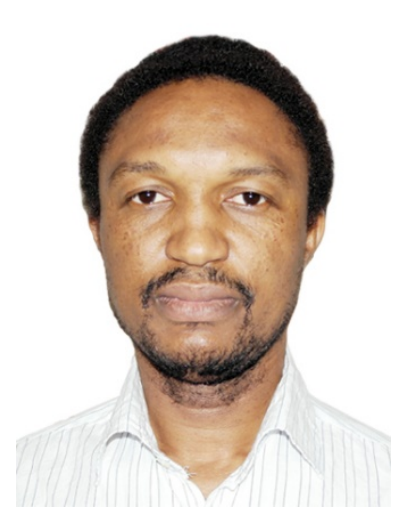

Christian Nedu Osakwe is a PhD Candidate of Management and Economics at the Faculty of Management and Economics, Tomas Bata University in Zlin, Czech Republic. He is equally a Seminar Lecturer of Applied Marketing Research, Principles of Marketing, and Brand Management at his university. His research interests are but not limited to strategic marketing, technology adoption/diffusion, micro, small and medium-sized enterprises (MSMEs), consumer behavior, as well as general socioeconomic issues related to emerging markets.

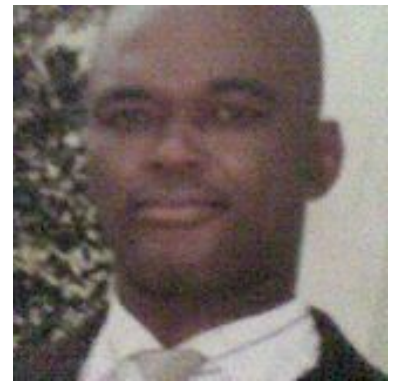

Dr. Titus Chukwuemezie Okeke holds a PhD in Marketing from Nnamdi Azikiwe University, Awka; a Master of Science MSc. (Marketing) Public Relations and Master in Business Administration (MBA) Marketing from the University of Nigeria, Enugu Campus. He is a specialist in data mining and analysis. His research interests are in the areas of electronic banking, electronic payment, mobile money, services marketing, government policy and business, poverty alleviation, consumer behaviour, internet marketing, retailing and pricing. 